\title{
A Study on the Demand of Foreign Language Talents Based on Regional Economic Development
}

\author{
Caiqiao Huo \\ Foreign Language Department, Baoding University, Baoding, China \\ Email: goofyhuo@163.com
}

Received 25 January 2016; accepted 2 April 2016; published 6 April 2016

Copyright ( 2016 by author and Scientific Research Publishing Inc. This work is licensed under the Creative Commons Attribution International License (CC BY). http://creativecommons.org/licenses/by/4.0/

(c) (;) Open Access

\begin{abstract}
Higher education should adapt to the local economic development and serve the local economic development, and therefore the training of foreign language talents in local colleges and universities should be based on the needs of local socio-economic development and the local market. It is necessary for the foreign language talents to participate in the regional economic development in Baoding City. The needs of foreign language talents have shown a trend of diversification, which requires the training of foreign language talents in local colleges and universities to be combined with the characteristics of economic development. In this paper, after the investigation including questionnaires, interviews and analysis of the recruitment information online, the author sums up the situation of the demand for foreign language talents and proposes some suggestions.
\end{abstract}

\section{Keywords}

Regional Economic Development, Foreign Language Talents, Needs

\section{Introduction}

In the process of emphasizing the internationalization of higher education, localization should also be emphasized. Talents should make contributions to the regional economic development, accelerating scientific and technological transformation for local use, optimizing local resources, and forming local-characterized industry. Foreign language is different from native language. The application of foreign language reflects that the knowledge and technology it carries has penetrated into all areas of society. In the industrial and management structures, the expansion and update of foreign languages and technology can affect a region's economic development direction and industry composition. As a tool of exchange and communication, foreign language plays an 
essential role in the field of economic development in Baoding. In the view of employment, if foreign language graduates can't be employed due to their own knowledge structure and cultural quality which are supposed to meet the social requirements, it means our education is a failure in a stage of market economy. With the adjustment of economic structure and the transformation of enterprises, foreign language talents are inseparable from regional economic development and the demand for foreign language talents has shown a diversification trend. Therefore, how to make the education of foreign language talents adapt to the rapid development of the industrial structure adjustment and economic reform in Baoding has become an important issue. This study aims to investigate the demand of foreign language talents in Baoding and provide some strategies for local higher education. The author bases the research on the regional economic development and combines the research with some local-characterized industries such as solar energy, car-making and handbag-production, etc., which is a new research field.

\section{Research Background}

Theodore William Schultz [1], an American economist, found that an important reason to promote the rapid growth of the US economy was not land, labor or capital stock increase, but to improve people's skills and knowledge in long-term economic study. His conclusion was that the speed of economic recovery was due to a healthy and highly educated population; education makes people productive and good healthcare keeps the education investment around and able to produce.

At the beginning of the 21st century, the United States issued a series of foreign language policies related to national security. In June of 2004, United States Department of Defense held the National Language Conference which involves the US government, enterprises, academics and language association leaders. The purpose of the conference was to improve the US leadership in the world by further understanding and respecting the world culture through improving national foreign language capabilities [2].

In China, Professor Hu Wenzhong from Beijing Foreign Studies University pointed out that foreign language education in our country had made important contributions in China's economic development, cultural exchanges, and diplomatic development. With the further deepening of reform and opening up, it was necessary to plan our foreign language education scientifically. In terms of the foreign language education planning, it involved politics, economy, culture, diplomacy, military and other aspects, therefore, we should base our planning on national conditions to promote foreign language education develop sustainably [3].

Professor Zhuang Zhixiang [4] from Shanghai International Studies University pointed out that China's foreign language majors developed rapidly since new China was founded sixty year ago, especially English majors, which made a significant contribution in the development of higher education and the cause of reform and opening up. But there exists some problems and contradictions in foreign language education, and how to deal with these problems and contradictions, especially between scale and need, quantity and quality, standards and characteristics, teaching and research, regression and development, etc. to make higher foreign language education develop sustainably and healthily is urgent.

Professor Dai Weidong [5] from Shanghai International Studies University emphasizes that under the background of economic globalization, foreign languages play an important and strategic role in improving our soft power. How to plan foreign language education and optimize the learning environment scientifically to promote the foreign language education develop soundly is vital.

Jiang Lei and Zuo Hongxia [6] pointed out that the cultivation of foreign language talents should serve the economic development of Henan Province. Chen Heng [7] emphasizes that the cultivation mode of foreign language talents should adapt to the economic structure and operation mechanism in Hengshui City and make sure that graduates can be employed by local enterprises.

\section{Study Design}

\subsection{The Objective of the Study}

In order to investigate the demand for foreign language talents in Baoding, and to find out the gap between foreign language professionals and market demand, the author investigated different kinds of enterprises, such as private enterprises, foreign-invested enterprises, joint-stock enterprises, and government-owned places, such as institution, society, the administrative agency. Most of the companies think they will need more foreign language tal- 
ents, who should not only be excellent in foreign language, but also have broad knowledge in the other fields.

\subsection{The Subject of the Study}

There are 515 companies involved in the survey, with 510 questionnaires taken back, of which 500 valid questionnaires. The recovery rate is $97 \%$. The companies are randomly selected in Baoding. Those companies do business in different fields, such as cars, solar energy, handbags, electronic products, agricultural products, etc.. There are 300 companies with more than 500 employees, 150 companies with 100 - 500 employees, 45 companies with 50 - 100 employees and 20 companies with less than 50 employees.

\subsection{Instruments}

The survey was conducted from January, 2015 to October, 2015. I made a questionnaire named IEDFLP (Investigation on Enterprise Demand for Foreign Language Professionals). Table 1 lists all the variables in the study.

\section{Data Analysis}

In order to know the specific requirements for foreign language talents, I made a simple descriptive statistics expressed as percentages, which is listed in the following Figure 1.

In Q1-Q3, these questions are about the general status of the involved companies, such as scale, need and demand of foreign language professionals. Q4-Q9 are about specific demands: 1) In Q4, which foreign languages does your company need, English occupies 89.5\%, Japanese occupies 43.4\%, French occupies 35.6\%, Spanish occupies 19.1\%, other foreign languages occupies 10.5\%. It indicates that English is used more widely than the other foreign languages. 2) In Q5, what is the demand for foreign language professionals, $28.7 \%$ of the companies declare that they need foreign language employees who are able to make strategies and promote implementation; $35.9 \%$ of the companies say they want their foreign language employees have the ability of staff management; $68.5 \%$ of the companies request that the foreign language employees can do the daily business operation. 3) In Q6, What kind of knowledge does your company focus on, except for foreign language communication skills, $88.7 \%$ of the companies claim that they hope these employees should know the related knowledge about that language, $60.8 \%$ of the companies require computer skills, $35.6 \%$ require these employees to have management skills, $18.6 \%$ of the companies require scientific knowledge, $10.9 \%$ of the companies require educational and psychological knowledge. 4) In Q7, What kind of ability does your company focus on except for foreign languages skills, $85.6 \%$ of the companies think cooperative ability is basic; $78.9 \%$ of the companies think executive ability is important; $54.7 \%$ of the companies think creative ability is important; $40.1 \%$ of the companies want the employees to have the independent thinking ability; $52.6 \%$ of the companies require the employees to have better study ability. 5) In Q8, Which of the comprehensive ability does your company focus

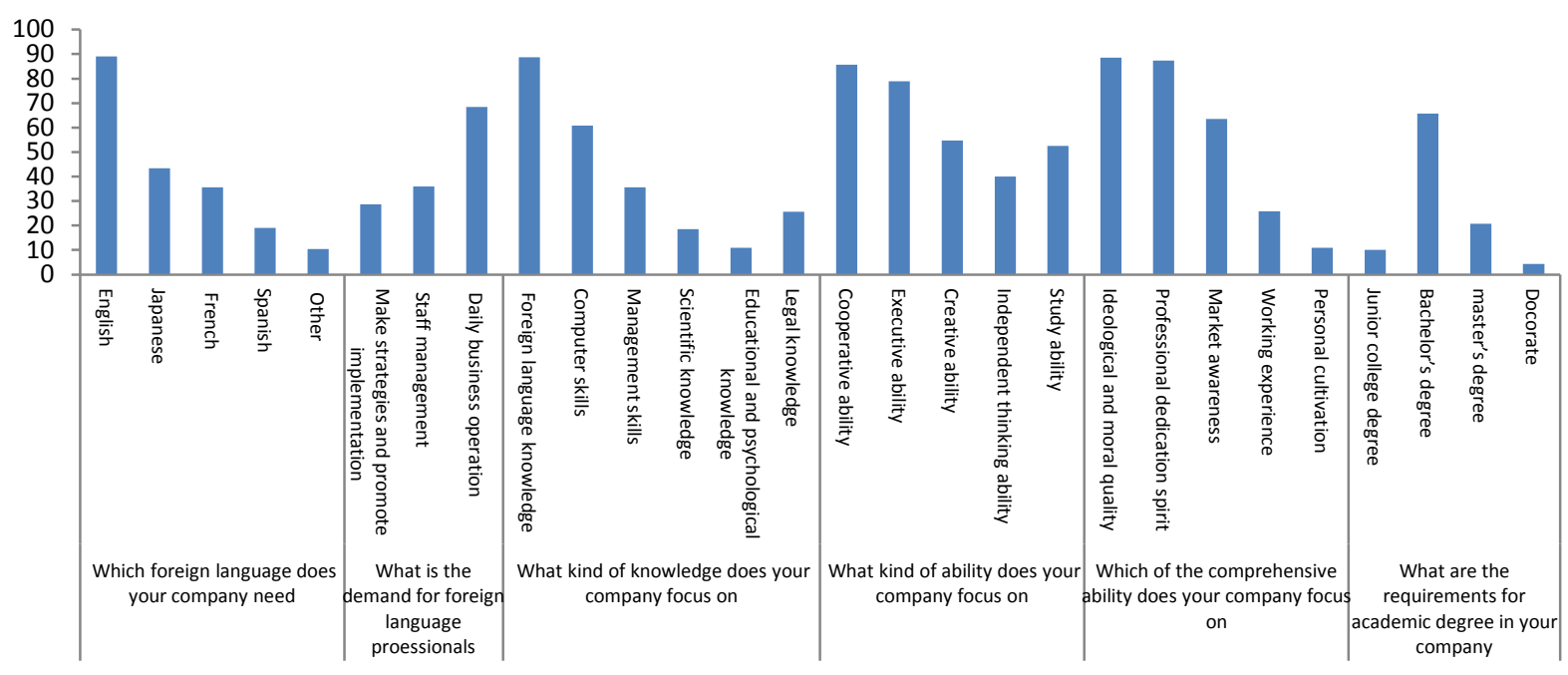

Figure 1. Special requirements for foreign language talents. 
Table 1. Description of the IEDFLP questionnaire.

\begin{tabular}{|c|c|}
\hline Variables & Description \\
\hline \multirow[t]{4}{*}{ Q1 Enterprise scale } & A less than 50 employees \\
\hline & B 50 - 100 employees \\
\hline & C 100 - 500employees \\
\hline & D more than 500 employees \\
\hline \multirow[t]{2}{*}{ Q2 Does your company have demand for foreign language professional? } & A Yes \\
\hline & B No \\
\hline \multirow[t]{2}{*}{ Q3 Are there foreign language professional in your company? } & A Yes \\
\hline & B No \\
\hline \multirow[t]{5}{*}{ Q4 Which foreign language does your company need? } & A English \\
\hline & B Japanese \\
\hline & C French \\
\hline & D Spanish \\
\hline & E other $10.5 \%$ \\
\hline \multirow[t]{3}{*}{ Q5 What is the demand for foreign language professionals? } & A Make strategies and promote implementation \\
\hline & B Staff management \\
\hline & C Daily business operation \\
\hline \multirow[t]{6}{*}{ Q6 What kind of knowledge does your company focus on? } & A Foreign language knowledge \\
\hline & B Computer skills \\
\hline & C Management skills \\
\hline & D Scientific knowledge \\
\hline & E Educational and psychological knowledge \\
\hline & F Legal knowledge \\
\hline \multirow[t]{5}{*}{ Q7 What kind of ability does your company focus on? } & A Cooperative ability \\
\hline & B Executive ability \\
\hline & C Creative ability \\
\hline & D Independent thinking ability \\
\hline & E Study ability \\
\hline \multirow[t]{5}{*}{ Q8 Which of the comprehensive ability does your company focus on? } & A Ideological and moral quality \\
\hline & B Professional dedication spirit \\
\hline & C Market awareness \\
\hline & D Working experience \\
\hline & E Personal cultivation \\
\hline \multirow[t]{4}{*}{ Q9 What are the requirements for academic degree in your company? } & A Junior college degree \\
\hline & B Bachelor's degree \\
\hline & C master's degree \\
\hline & D Doctorate \\
\hline \multirow[t]{2}{*}{$\begin{array}{l}\text { Q10 Is your company willing to provide internship } \\
\text { opportunities for foreign language majors? }\end{array}$} & A Yes \\
\hline & B No \\
\hline \multirow[t]{2}{*}{ Q11 Is your company willing to cooperate with foreign language departments? } & A Yes \\
\hline & B No \\
\hline Q12 What suggestions can you offer? & \\
\hline
\end{tabular}


on, $88.6 \%$ of the companies focus on ideological and moral quality, $87.4 \%$ of the companies hope the employees to have the spirit of dedication; $63.5 \%$ of the companies need the employees to have the ability of market awareness; $25.8 \%$ of the companies require the applicants to have working experience; $10.9 \%$ of the companies need the employees to have personal cultivation. 6) In Q9, what are the requirements for academic degrees in your company, $10.1 \%$ of the companies claim that junior college degree is OK; $65.8 \%$ of the companies claim that applicants should at least get bachelor's degree; $20.7 \%$ of the companies claim that they want the applicants to have obtained master's degree; $4.4 \%$ of the companies claim that they need some applicants with doctorate. In Q10-Q12, the companies investigated are willing to provide internship opportunities to foreign language graduates and they also give the local universities some suggestions which will be discussed in details in the next section.

\section{Discussion}

As for foreign language applicants, there are no specific requirements on gender, image, colleges and universities where they graduate from, but most of the companies require graduates to have at least got bachelor's degree. English is still more widely used than the other foreign languages. The positions provided are not confined to translation or teaching. There are diversified positions available, such as assistant manager, marketing specialist, foreign trade personnel, management personnel, etc. For translation companies and universities, they have higher standards for applicants' degrees and universities where the applicants graduate from; they also require the applicants to be good at relevant professional knowledge. Among different kinds of skills for foreign language talents, speaking ability comes first, which determines the first impressions applicants leave on their employers. As for comprehensive ability, study ability and cooperation ability are valued [8]. Besides relevant professional knowledge, computer skills, management ability, innovation ability, independent thinking ability are valued. Most of the large private enterprises need more foreign languages, but for small private enterprises, English is widely required.

The basic issue of talent training is to promote students' knowledge, ability and comprehensive coordinated development. No matter what kind of foreign language training mode is taken, educators should focus on the following aspects:

\section{1) Changing the concept of training foreign language talents}

Administrators and teachers in universities are still at a learning, imitation stage in terms of training all-round foreign language talents. In the process of foreign language teaching, we have to solve the contradiction between unity and diversity and make knowledge, ability and quality develop harmoniously. The current situation in our university is that: More time is spent on theory class than practice class; Many teachers are still teaching in the traditional way and seldom think about students' adaptability; Too much emphasis is put on knowledge while students' personality cultivation is ignored. Therefore, educators should change their concept of training foreign talents. According to the new concept, we should change our teaching methods and adjust teaching contents to make students study happily and healthily [9].

\section{2) Strengthening basic foreign language skills teaching}

It is significant to strengthen students' foreign language skills no matter what kind of training methods are taken in universities. Foreign language is the advantage of foreign language majors, so basic skills such as listening, speaking, reading, writing and translating should always be placed at the dominant position. Educators should reform the conventional teaching contents. At the same time, create better learning circumstances to promote knowledge acquisition, thinking patterns, learning ability and innovation ability. After students grasp the basic language skills, cultivate students' international cross-cultural awareness and make students communicate skillfully in such fields as international trade and law and know how to reconcile collisions.

\section{3) Adding minor courses}

For foreign language majors, there are two main forms to minor in other professionals: one is to increase the proportion of science, law, economy and trade courses in the whole foreign language professional curriculum and adopt bilingual or foreign language teaching method; the other is to strengthen the guidance of tutor, combine two disciplines organically and improve two kinds of professional ability interactively. In doing these, keep in mind that foreign language is the major, other disciplines are the minor. The focus of the major should be put on listening, speaking, reading, writing and translation; the focus of the minor is to learn preliminary knowledge and skills [10].

4) Pay attention to cultivate students' comprehensive quality

On the basis of training students to acquire language and professional knowledge, promote students' all-round 
development. Universities should break the barriers between literature, history, philosophy and classics and list improving students' comprehensive humanistic quality on the teaching plan. Combine knowledge acquisition and cultural quality education together. Cultivate students' sense of social responsibility. Broaden students' international horizon. Make students absorb the essence of world culture and inherit excellent traditional Chinese culture to meet the demand of the international communication under the background of globalization. All of these are significant to cultivate students' innovative thinking ability and character.

\section{5) Strengthen the construction of the teachers}

In order to cultivate foreign talents who are good at foreign language and other professional knowledge, universities need a certain number of qualified interdisciplinary foreign language teachers. At present, most of the teachers are foreign language professionals who are masters of foreign languages but lack of cross-disciplinary knowledge. Therefore, it is urgent for universities to optimize and strengthen the construction of teaching staff. First, the foreign language departments or colleges can cooperate with other departments or colleges and share resources; second, they can establish and improve the teachers' training mechanism to encourage teachers to get cross-disciplinary training; third, according to the needs of subject construction, they can hire other experienced experts or professionals as teachers to give lectures or guidance to students.

\section{Conclusion}

This paper analyzes the demand for foreign language talents in Baoding city after the author did some research. There are still some limitations of this study, such as the local foreign language graduates' targeted working places, the foreign language professional's demand of the local companies, etc., which needs to be further studied. But all in all, training strategies should keep consistent with the need of the market. Applied and interdisciplinary diversified training is an inevitable trend in the $21^{\text {st }}$ century. It brings us both opportunities and challenges. Universities should seize the opportunities and change the out-dated teaching ideology to cultivate more qualified foreign language talents [11].

\section{Acknowledgements}

The paper is under the project of Research on the Demand of Foreign Language Talents Based on Regional Economic Development-Take Baoding as the Case (Project No. 151021) which is sponsored by Baoding Municipal Institute of Education and Teaching. All the project members made their contributions to the paper. I also thank all my friends and classmates who work in different universities, which made the investigation possible.

\section{References}

[1] Schultz, T.W. (1990) Investment in Human Capital: The Role of Education and of Research. Commercial Press, Beijing.

[2] Wang, J.Q. (2007) National Language Strategy of US and Language \&Culture Security of China. Journal of International Chinese Language Teaching \& Learning, 2, 3-11.

[3] Hu, W.Z. (2009) The Achievements and Defects of China's Foreign Language Education in the Past Sixty Years. Journal of the Foreign Language World, 5, 10-17.

[4] Zhuang, Z.X. (2010) Some Reflections on the Construction and Development of Foreign Language Major in China. Journal of the Foreign Language World, 1, 3-10.

[5] Dai, W.D. and Wang, X.M. (2011) A Revist to Foreign Language Education Planning in China under the Background of Globlization. Journal of the Foreign Languages in China, 2, 4-11.

[6] Jiang, L. and Zuo, H.X. (2004) On Regional Economic Development and Foreign Language Talents Training. Journal of Henan Finance \& Taxation College, 6, 38-39.

[7] Chen, H. (2014) Research on Foreign Language Talents Cultivation Mode Based on Local Economy. Journal of Internet World, 14, 280.

[8] Shao, Z.N. (2015) Demand of Foreign Language Talents under the Background of Integration of the Beijing-TianjinHebei Region. Journal of English Square (Academic Research), 1, 93-95.

[9] Guo, J.W. (2014) Training of Foreign Language Talents in Jiangsu. Journal of Huanggang Polytechnic, 2, 32-35.

[10] Ren, H.X. and Zhang, C.L. (2009) An Analytical Study of Application-Based Foreign Language Teaching in Universities. Journal of Hehei Normal University (Educational Science Edition), 8, 128-131.

[11] Shi, J.Z. and Zhao, Y.X. (2010) Strengthen the Training of Foreign Language Talents. Journal of Intelligence, $30,304$. 